\title{
Economic and Social Distr.
} Council

GENERAL

E/CN.4/Sub.2/2001/28

2 August 2001

Original: ENGLISH

COMMISSION ON HUMAN RIGHTS

Sub-Commission on the Promotion and

Protection of Human Rights

Fifty-third session

Item 6 of the provisional agenda

\section{OTHER ISSUES}

Report of the Secretary-General on the situation of women and girls in the territories occupied by Afghan armed groups, submitted in accordance with Sub-Commission resolution 2000/11
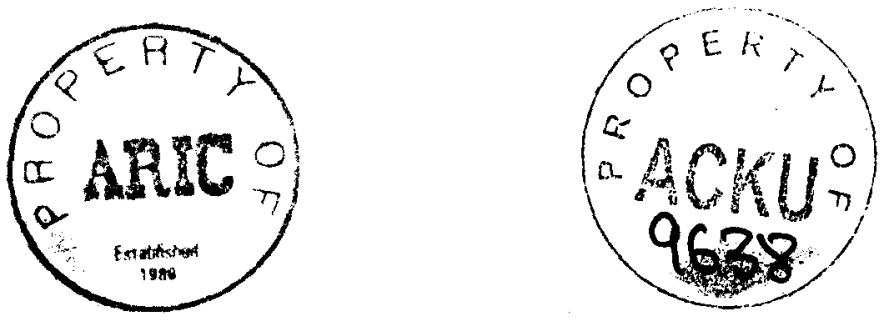

GE.01-14808 (E) 070801 


\section{Introduction}

1. The present report is submitted in accordance with resolution $2000 / 11$, in which the Sub-Commission requested the Secretary-General to continue to make available all the information that could be compiled on the situation of women and girls in the territories controlled by Afghan armed groups.

2. This report supplements the report submitted to the Commission on the Status of Women at its forty-fifth session in March 2001, entitled, "The situation of women and girls in Afghanistan" (E/CN.6/2001/2/Add.1). The earlier report provides an overview of the situation of women and girls in Afghanistan against a background of deteriorating socio-economic conditions, continued conflict and the prevalence of discriminatory attitudes and practices, including discriminatory edicts issued by the Taliban authorities. The report also contains information about actions taken by the United Nations system and the assistance community to improve the situation of women and girls in Afghanistan as recommended by the Economic and Social Council in its resolution 2000/9. To avoid duplication the present report will only include relevant new developments/material since March 2001 and should be read together with the earlier substantive report, which will be circulated at the Sub-Commission as a reference document.

3. In recent months the following resolutions have been adopted on the situation of women and girls in Afghanistan.

4. At its forty-fifth session, in March 2001, the Commission on the Status of Women, acting without a vote, recommended that the Economic and Social Council adopt a resolution on discrimination against women and girls in Afghanistan. It strongly condemned the continuing grave violations of the human rights of women and girls, including all forms of discrimination against them in all areas of the country, particularly in those under the control of the Taliban. It also condemned the continued restrictions on women's access to health care and the systematic violation of their human rights in Afghanistan, including the restrictions on access to education and employment outside the home, on freedom of movement and on freedom from intimidation, harassment and violence.

5. At its fifty-seventh session, in April 2001, the Commission on Human Rights adopted, without a vote, resolution 2001/13 on the situation of human rights in Afghanistan, in which it strongly condemned the mass killings and systematic human rights violations against civilians and persons deprived of their liberty, for reasons related to the armed conflict, resulting in the massive, forced displacement of the civilian population. It also noted with deep concern the continuing pattern of human rights violations in Afghanistan and the continuation of armed hostilities and the complex nature of the conflict, including its ethnic, religious and political aspects, which had resulted in extensive human suffering and forced displacement. Furthermore, the Commission condemned the continuing grave violations of the human rights of women and girls and urged all Afghan parties to respect fully all human rights. The Commission decided to extend the mandate of the Special Rapporteur on the situation of human rights in Afghanistan for a further year. 


\section{The conflict}

6. As stated in the earlier report, the conflict is both an outcome of and a factor contributing to the protracted crisis. Mitigating the conflict and ameliorating the way it is prosecuted are essential for improving the situation of women and girls, as well as men and boys. Other factors relating to the conflict, include profound underdevelopment, widespread poverty, lack of representative governance mechanisms and official gender discrimination, must also be addressed.

7. The conflict and its destructive impact on communities and the right to life, and the accumulated and indirect effects of war contribute to a massive human rights deficit. This deficit includes denial of the right to food, the right to health and the right to education. Nor do Afghans enjoy freedom from fear or freedom of association. The collapse of civil society and the limited ability of Afghans to participate in or influence decision-making have a direct negative impact on their right to life and other rights essential for livelihood and survival with a modicum of dignity. Women and girls suffer disproportionately in the realization and enjoyment of all their rights and there are few current indications that this situation will improve significantly in the near future.

8. State and non-State actors across the region and beyond continue to provide new arms, ammunition, fuel and other logistical support, as well as training and advisory assistance to the parties to the conflict in Afghanistan. The arms provided have been directly implicated in serious violations of international humanitarian law.

9. Reports supported by reliable eyewitnesses document the summary executions and massacres carried out in January 2001 in Yakawlang. These reports indicate that, in the taking and retaking of Yakawlang, breaches of humanitarian law were committed by both parties as they violated the neutrality of medical facilities in the district and disregarded the rights of civilians to be treated as non-combatants. Yakawlang was captured by United Front forces (Hezbe Wahdat and Harakat Islami) on 28 December 2000 and recaptured by the Taliban in early January 2001. Taliban forces reached the district centre of Nayak in the morning of 8 January 2001. There are reports of mass arrests followed by summary executions carried out by Taliban forces between 8 and 12 January 2001. A number of aid agency personnel and a United Nations staff member were among those killed during this period. ${ }^{1}$

10. On 16 February 2001, the United Nations High Commissioner for Human Rights published a statement on Afghanistan. In view of the repeated massive violations of human rights and humanitarian law in Afghanistan, the High Commissioner called upon the international community to establish an independent international inquiry into the massacres and other grave human rights violations committed by parties to the armed conflict in Afghanistan. This statement was made in the context of reports of, inter alia, the summary execution of civilians by Taliban forces in the Yakawlang district of the province of Bamyan in January 2001.

11. The pattern of systematic burning of houses and wide-scale arbitrary detentions continues. On 15 June 2001, the Secretary-General issued a statement expressing concern at the alarming reports from Afghanistan of indiscriminate bombing, including attacks on the District Hospital and local aid agency facilities, and violence against civilians during the takeover of 
page 4

Yakawlang by Taliban forces on 11 June. The Secretary-General was also disturbed at the reported widespread burning of homes and other property and at the large number of civilians said to have been detained and removed from the area. He expressed his dismay at the persistent failure of the warring parties to abide by international humanitarian norms and to hold those responsible for gross violations of human rights accountable for their actions. The Secretary-General urged the international community and human rights organizations to explore new approaches that would prevent further abuses and put an end to the climate of impunity.

12. The Special Rapporteur on the situation of human rights in Afghanistan stated in his report to the Commission on Human Rights at its fifty-seventh session that, in order to deter and prevent the occurrence of such atrocities, an effective international initiative was needed to expose and hold to account those responsible for war crimes, breaches of international humanitarian law and gross violations of human rights. International cooperation was needed to deny impunity and enforce accountability by developing mechanisms to undertake a full investigation to gather evidence and to identify those responsible in order that they might be brought to justice. The findings of that investigation would provide a basis for enforcing accountability through appropriate mechanisms at the national and international levels (E/CN.4/2001/43/Add.1, paras. 10 and 13).

\section{The Food crisis}

13. According to the FAO/WFP crop and food supply assessment, ${ }^{2}$ Afghanistan faces a much more serious food crisis this year than last year as a consequence of severe drought for the third consecutive year and intensifying economic problems. The food situation is rapidly deteriorating and will continue to worsen as the current marketing year (2001/02) progresses. There is mounting evidence of emerging widespread famine conditions in the country, reflecting substantially reduced food intakes, collapse of the purchasing power of the people, distress sales of livestock, large-scale depletion of personal assets, soaring food grain prices, rapidly increasing numbers of destitute people, and ever swelling numbers of refugees and internally displaced persons.

14. Poor access to drinking water in many villages has an impact on the incidence of water-borne diseases, as exemplified by the high incidence of diarrhoea and dysentery in many areas. The situation will probably continue to worsen as the food deficit, aggravated by a poor harvest, takes its toll on the local population. In remote districts, few, if any, aid organizations are operating, because of access and logistical constraints.

15. The high level of food insecurity and water scarcity has a particular impact on women and children. One effect of the growing poverty is that many male breadwinners are leaving their homes in search of work in neighbouring countries or within Afghanistan, while women and children are left behind either in settlements for internally displaced persons (IDPs) or at their places of origin. Moreover, the need to prioritize expenditure and lack of money for food mean that women and girls suffer disproportionately. Women tend to reduce their own food allowance in favour of the men, because they are "workers", and children. The amount of money available for women's medical costs and transport to the nearest health centre will 
decrease, putting them at greater risk of maternal mortality. Further, women and children are the main water-collectors and, with the increasing scarcity of potable water in drought-affected areas, they have to walk longer distances to fetch water - sometimes five or more kilometres.

16. In remote rural areas, the situation is particularly difficult in terms of food security and is aggravated by the fact that there are no road links to the outside world, which can only be reached on horseback or on foot. In some areas, many of the local population have already left their homes and gone to swell the number of IDPs in camps or have left for Pakistan and Iran. If steps are not taken to address the situation, it can be estimated that a significant portion of the local population could become displaced in the coming months.

\section{Female IDPs and refugees}

17. Since mid-2000, up to 700,000 Afghans, the vast majority of whom are women and children, have left their homes because of conflict, drought and human rights violations. They have flocked to the bigger towns and cities or crossed the border into Iran and Pakistan.

18. The Senior Inter-Agency Network on Internal Displacement, led by the United Nations Special Coordinator on Internal Displacement, together with representatives of FAO, UNHCR, UNDP, UNICEF, WHO and the NGO community, undertook a mission to Afghanistan from 18 to 25 April 2001. They assessed the nature and magnitude of the crisis affecting internally displaced populations and related vulnerable populations, particularly women and children, including those at risk of being displaced. Their report confirms that the condition of women in Afghanistan is dramatic: the Taliban have pursued a policy of marginalization of women and girls, including by placing a ban on education, prohibiting women from working outside the house and restricting their freedom of movement. However, the application of such restrictions has been inconsistent, allowing the humanitarian community to devise various entry points to reach some women and girls in need. They made a series of proposals, which are included in the recommendations section of the present report (see para. 34, below).

19. According to recent statistics provided by UNHCR, the gender and age profile during the period January-May 2001 of households covering a total of 13,140 returnees was as follows: of the interviewed returnees, 52 per cent had returned from Pakistan and 48 per cent from Iran. In the eastern and southern regions, all those interviewed had returned from Pakistan. Fifty-two per cent of the Afghan returnees interviewed were male and 48 per cent female. Of the total number of returnees, 25 per cent are children below school age, 30 per cent are between 6 and 18 years of age. Of the interviewed heads of returnee families, 95 per cent were men, while 5 per cent were women (109 families). Ten per cent of the returnee families have one or two physically, psychologically or socially vulnerable family members. Forty-six per cent of the interviewed returnee families have access to health services within reachable distance $(2-38 \mathrm{~km})$ from their place of return, while the majority - 56 per cent - of those interviewed have no access to any kind of health service - mobile or permanent health unit, doctor or clinic. Of the school-age children of returnee families interviewed in 2001, 69 per cent are not attending any school, either public or home-based, or receiving madrasa or mosque-based education. Twelve per cent of the male returnee children are receiving education in madrasas or mosques, 10 per cent in public schools and 1 per cent in home-based schools. Of the girls, 5 per cent are receiving education in madrasas or mosques, 2 per cent in home-based schools (in the western 
page 6

region) and 1 per cent in public (community based) schools. However, interest among returnee families in sending their children, including girls, to school continues to be very high among 87 per cent of the interviewed heads of returnee households. Among the reasons for not doing so, the lack of a school facility was among the reasons primarily mentioned, while only 13 per cent of the returnee families referred to restrictive policies on the part of the authorities. After more than two decades of conflict, Afghanistan has some of the worst education indicators in the world according to a UNICEF Afghanistan paper entitled "Education - a chronic emergency in Afghanistan". It records how access is low at all levels, especially for girls, but also for boys. According to recent UNESCO data, as few as 3 per cent of Afghan girls and 39 per cent of boys in the relevant age groups may be attending some form of primary education, the quality of much of which remains poor.

\section{Official gender discrimination}

20. The policy and practices of the Taliban authorities, which exacerbate the discrimination already suffered by Afghan women, continue to be a major concern. Physicians for Human Rights recently released a population-based study aimed at documenting the degree to which Afghan women perceive that violations of human rights by the Taliban regime affect their health and well-being. It assesses the Afghan people's attitudes towards women's human rights and the importance of these rights for community health and development in Afghanistan. While noting that women's suffering in Afghanistan may be caused by a number of factors, not simply Taliban policies, the study focuses particularly on the effects of official policies of discrimination against women. Physicians for Human Rights underlines that policies restricting women's rights are not the product of years of conflict and social and economic deprivation, which are arguably difficult to resolve; they are man-made policies that can be revoked as easily and swiftly as they came into being. It reports that, although the Taliban claim that their gender policies are rooted in Afghan history and culture, this claim is contradicted by the views of the Afghan women and men in the study. Over 90 per cent of Afghan women and men surveyed by Physicians for Human Rights strongly support rights for women currently restricted by the Taliban regime, including equal access to education and work opportunities, freedom of expression, legal protection of women's human rights and participation in government. They also agree that women's human rights issues should be included in peace talks. Approximately 80 per cent of women and men agreed that women should be able to move about freely and that the teachings of Islam do not restrict women's human rights. Seventy-five per cent of women and men expressed the view that women should be able to associate with people of their own choosing.

21. Some commentators have raised concerns about the methodology used for the study, including the way the questions were formulated and presented. The main concern was that the Physicians for Human Rights statement oversimplifies the problem and that attitudes and beliefs are much more complicated than the study indicates. Nevertheless, its finding that the vast majority of both Afghan women and men support women's rights provides an insight into the extent to which Taliban policies appear to fail to represent the interests of the Afghan people.

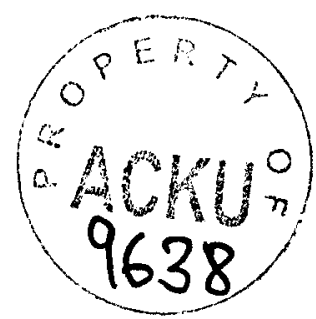


E/CN.4/Sub.2/2001/28

page 7

\section{The narrowing humanitarian space for the United Nations and the aid agencies}

22. There has been a narrowing of the humanitarian space available for relief agencies to operate effectively in Afghanistan since the beginning of the year, which has severe implications for vulnerable groups of the Afghan population who are dependent on international assistance. The consequences of the increasingly difficult operating environment include: reduced ability to work with or access women; inability to reach populations that are a low priority for the Taliban authorities; and generally increased costs to the extent that otherwise viable projects have to be considered for closure. A continued deterioration of the operating conditions, to the extent where staff security cannot be assured, could ultimately force aid agencies to withdraw and suspend operations. ${ }^{3}$ A chronology of recent incidents is provided below.

23. On 25 May 2001 the World Food Programme (WFP) announced that it would have to suspend its bakery programme by 15 June unless the Taliban allowed a survey to be conducted to identify the capital's "most needy". The list of approved beneficiaries of the bakery project was outdated and many hungry people had to do without. WFP said it needed to hire between 20 and 30 Afghan women to conduct the survey, but the Taliban refused to allow them to hire local women. In a meeting with a United Nations team, the Taliban foreign minister, Mowlawi Wakil Ahmad Mutawakkil, suggested that, if the five-year-old bakeries were forced to close, the Islamic Emirate (Taliban) authorities could take over the running of the programme. The Taliban also proposed two alternative options. The first was to hire men to conduct the survey, in spite of the fact that, under Islamic Emirate rules, men cannot talk to women. The second option was to hire women of Pakistani, Tajik or Iranian nationality. The United Nations team indicated its opposition to both those proposals. A final agreement was reached on 17 June 2001, although it has yet to be implemented. Part of the arrangement is that Ministry of Public Health (MOPH) females, selected jointly by WFP and MOPH, will undertake a survey to determine vulnerability.

24. The Taliban authorities in Afghanistan have ordered that female aid workers are not to drive vehicles. A letter issued by the Taliban religious police in May 2001 stated that foreign women driving cars in Afghan cities was "against Afghan traditions and has a negative impact on the environment". It states that in future, foreign women must not drive cars and must "abide by the regulations of the Islamic Emirate (of Afghanistan)".4

25. An increasing number of visitors to Afghanistan, known as "guests", from the Gulf and other countries, have been directing abuse and sometimes death threats at aid workers and United Nations staff. Equally, the conduct of the Taliban's religious police from the Ministry for the Prevention of Vice and Promotion of Virtue has become increasingly hard-line, including engaging in indiscriminate arrests.

26. On 24 June 2001, police from the Ministry for the Prevention of Vice and Promotion of Virtue raided an Italian-funded emergency hospital in Kabul, beating several staff members and forcing the hospital to suspend operations, because male and female staff allegedly mixed in the dining area and operating wards. The Taliban authorities have also recently blocked the delivery of humanitarian aid to large parts of the Hazarajat region, which is populated mainly by Shia Muslims and includes centres of armed opposition activity. 
27. The Under-Secretary-General for Humanitarian Affairs and Emergency Relief Coordinator has expressed his concern about the increasing harassment and abuse of Afghan national staff of the United Nations and the NGO community and about restrictions on programmes that attempt to help women as well as men. He has called upon the Taliban to take immediate steps to improve the working environment of the humanitarian community. ${ }^{5}$

28. The United Nations is working to maintain "humanitarian space" and to secure the Taliban's compliance with the Humanitarian Operational Requirements (HOR) document. ${ }^{6}$ The HOR is an agreement which was reached with the Taliban on a number of "basic operational requirements", including the need for free and unhindered access for aid workers, security of staff, the ability to assess and monitor programmes independently, and the need for such programmes to be based on "universality, impartiality and neutrality".

\section{Conclusions}

29. The paper entitled "Assistance and human rights in war-torn Afghanistan: challenge and opportunity", prepared for the meeting of the Afghanistan Support Group held in December 2000 , succinctly depicts the situation which needs to be addressed if human rights are to be protected against further deterioration:

"It is increasingly apparent that the coping capacity of those who are most vulnerable has been severely weakened as a result of the war; the majority of the population struggles to survive at near subsistence levels. The situation of females, including in particular female-headed households, is of particular concern given the many old and new restrictions that limit their ability to provide for themselves and their families. Indeed, for women and men alike there are very few job opportunities outside the subsistence economy; for many, the only available option is the criminalized economy or relocation to another area. Afghanistan's socio-economic indicators are well known and are likely to get worse as the drought takes its toll and the underlying causes of poverty and underdevelopment are largely ignored. It is this reality - coupled with the knowledge of what was possible in pre-war Afghanistan - which should motivate the international community to tackle the dynamics which contribute to a worsening of the crisis and with it a further deterioration of the human rights situation."

30. Furthermore, in order to prevent the occurrence of further atrocities, an effective international initiative is needed to expose and hold to account those responsible for war crimes, breaches of international humanitarian law and gross violations of human rights. International cooperation is needed to deny impunity and enforce accountability by developing mechanisms to undertake full investigation, gathering evidence and to identifying those responsible in order that they may be brought to justice. The Taliban authorities and the Islamic State of Afghanistan will be expected to respect their obligation to cooperate in the carrying out of these investigations. The findings of these investigations would provide a basis for enforcing accountability through appropriate mechanisms at the national and international levels. 
E/CN.4/Sub.2/2001/28

page 9

\section{Recommendations}

31. All Afghan parties must:

Respect human rights, international humanitarian law and safeguards for humanitarian space;

Bring to an end without delay all violations of the human rights of women and girls and take urgent measures to ensure the repeal of all legislative and other measures, which discriminate against women;

Take urgent measures to ensure the effective participation of women in civil, cultural, economic, political and social life throughout the country, respect the right of women to work; the right to education without discrimination; respect for women's right to security of person; respect for women's freedom of movement and effective and equal access to facilities necessary to protect their right to the highest attainable physical and mental health;

Ensure the safety and protection of all United Nations and humanitarian workers in Afghanistan and allow them, regardless of gender, to carry out their work unhindered.

32. The international community must:

Take proactive measures to end the conflict which continues to be externally supported; take meaningful measures to address the issue of impunity;

Support the efforts of the aid community to improve the protection of civilians in particular women and children (including the allocation of more resources);

Continue to call for the repeal of all edicts and the end to all forms of gender discrimination;

Continue to give special attention to the promotion and protection of the human rights of women and girls in Afghanistan and to mainstream a gender perspective into all aspects of policies and actions related to Afghanistan.

33. The United Nations and its partners should be supported to:

Continue to ensure that all United Nations-assisted programmes in Afghanistan are formulated and coordinated in such a way as to promote and ensure the participation of women in those programmes, and that women benefit equally with men from such programmes;

Establish culturally sensitive programmes to sensitize Afghan officials, ministry staff and technical departments concerning international principles of human rights and gender equality; 
Undertake research that provides better data and information on the situation of women and girls in all areas of the country;

Develop a set of United Nations policy guidelines to deal with issues such as international women being asked to leave meetings, national women's security and mobility;

Women must be brought into all levels of the United Nations, furthermore, those with gender-specific expertise must be included in senior management if the United Nations is to develop appropriate and effective policies to protect and assist women and girls.

34. The Senior Inter-Agency Network on Internal Displacement, in the final report on its mission to Afghanistan from 18 to 25 April 2001, recommended that:

Humanitarian agencies increase their presence in the field to reinforce mechanisms in order better to reach female populations and respond to their needs; and that they continue advocating with the authorities for the rights of women and girls and ensuring that protection and promotion of such rights are incorporated in their programming;

UNCO and UNICEF undertake an assessment of the impact of displacement on women and children, comparing inter alia the status of health (mental and physical) and the coping mechanisms of the displaced and the local population;

UNICEF strengthen child protection programmes, including for psycho-social rehabilitation, using this as an entry point for longer-term education.

\section{$\underline{\text { Notes }}$}

1 See Report on the situation of human rights in Afghanistan submitted by Mr. Kamal Hossain, Special Rapporteur, E/CN.4/2001/43/Add.1, and "Afghanistan: Taliban massacres detailed", Human Rights Watch press release, 19 February 2001.

27 June 2001, FAO/WFP Crop and Food Supply Assessment Mission to Afghanistan, see www.pcpafg.org.

3 Report of the Secretary-General on the humanitarian implications of the measures imposed by Security Council resolutions 1267 (1999) and 1333 (2000) on Afghanistan, S/2001/695, 13 July 2001.

${ }^{4}$ BBC News, Thursday, 31 May 2001.

5. 27 June 2001, UN Weekly Update.

${ }^{6}$ See Memorandum of Understanding between the Islamic Emirate of Afghanistan and the United Nations signed on 13 May 1998 and the Supplementary Protocol signed on 24 October 1998.

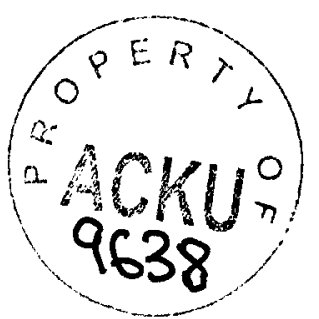

